\title{
Complex Karyotype
}

National Cancer Institute

\section{Source}

National Cancer Institute. Complex Karyotype. NCI Thesaurus. Code C97138.

Karyotype with at least three chromosomal aberrations. 